\title{
Gambaran Tingkat Depresi Pada Lansia Yang Tinggal Dipanti Sosial : Literature Review
}

\author{
Kiki Alfiatur Rohmaniah', Dyah Putri Aryati2* \\ ${ }^{1,2}$ Program Studi Sarjana Keperawatan, Universitas Muhammadiyah Pekajangan \\ Pekalongan, Indonesia \\ *email : putri.ners89@gmail.com
}

\begin{abstract}
Changes in physical, mental, and sosial function are factors that often lead to psychosocial problems such as depression in the elderly. There is also another factor that causes depression in the elderly is the place of residence. The elderly who lives in care homes are more at risk of experiencing depression. Depression is a common mental health disorder characterized by feelings of depression, guilt, sleep disturbances, decreased appetite, loss of pleasure or interest, feeling less energy, and decreased concentration. The impact of prolonged depression in the elderly can reduce health status, the emergence of self-injury behavior to attempt suicide. To describe the level of depression in the elderly living in care homes. A descriptive study method with a literature review approach. In the search for articles using Google Scholar and the PubMed database. Articles were selected based on the suitability of the specified inclusion and exclusion criteria. There were five articles published in 2011-2020 and using the Geriatric Depression Scale measuring instrument. The critical assessment instrument used is the Joanna Briggs Institute Critical Appraisal. The review result of the five articles showed that there were 112 people (24.2\%) who experienced the normal level of depression, 234 people $(50.3 \%)$ who experienced the mild level of depression, 90 people $(19.3 \%)$ who experienced the moderate level of depression, and 29 people $(6.2 \%)$ who experienced the major level of depression. The incidence of depression in the elderly must be addressed immediately, both non-pharmacologically and psychologically so as not to cause effects such as self-injury behavior to attempted suicide.
\end{abstract}

Keywords: elderly; care home; depression level

\section{Abstrak}

Perubahan fungsi fisik, mental dan sosial merupakan faktor yang seringkali mengakibatkan terjadinya permasalahan psikososial salah satunya depresi. Selain dari faktor tersebut ada faktor lain yang menyebabkan depresi pada lansia yaitu tempat tinggal. Lansia yang tinggal di panti sosial lebih beresiko mengalami depresi. Depresi merupakan gangguan kesehatan mental umum yang ditandai dengan perasaan yang tertekan, perasaan bersalah, terjadi gangguan istirahat tidur, nafsu makan menurun, kehilangan kesenangan atau minat, merasa kurang berenergi serta konsentrasi menurun. Dampak dari depresi pada lansia yang berkepanjangan dapat menurunkan status kesehatan, munculnya tingkah laku melukai diri sampai melakukan percobaan bunuh diri. Mengetahui gambaran tingkat depresi pada lansia yang tinggal di panti sosial. Menggunakan metode studi deskriptif dengan pendekatan literature review. Dalam pencarian artikel menggunakan Google Scholar dan database PubMed. Artikel diseleksi berdasarkan kesesuaian kriteria inklusi dan eksklusi yang ditentukan. Didapatkan lima artikel yang dipublikasikan pada tahun 2011-2020 dan menggunakan alat ukur Geriatric Depression Scale. Instrumen telaah kritis yang digunakan adalah Joanna Briggs Institute Critical Appraisal. Hasil review dari kelima artikel lansia dengan kategori normal sebanyak 112 orang (24,2\%), depresi ringan sebanyak 234 orang $(50,3 \%)$, depresi sedang sebanyak 90 orang (19,3\%), dan depresi berat sebanyak 29 orang $(6,2 \%)$. Kejadian depresi pada lansia harus segera diatasi baik secara non farmakologi ataupun psikologis agar tidak memunculkan dampak seperti tingkah laku melukai diri sampai melakukan percobaan bunuh diri.

Kata kunci : lansia ; panti sosial ; tingkat depresi 


\section{Prosiding Seminar Nasional Kesehatan 2021 \\ Lembaga Penelitian dan Pengabdian Masyarakat Universitas Muhammadiyah Pekajangan Pekalongan}

\section{Pendahuluan}

Undang-Undang Nomor 13 Tahun 1998 menyebutkan bahwa lansia merupakan seseorang yang telah mencapai usia 60 tahun ke atas [1]. Jumlah lansia di seluruh dunia pada tahun 2016 sekitar 500 juta jiwa dan pada tahun 2025 diperkirakan akan mencapai 1,2 milyar [2]. Pada lansia perubahan fungsi fisik, mental dan sosial merupakan faktoryang seringkali mengakibatkan terjadinya permasalahan psikososial salah satunya depresi.

World Organization Health [3] menyebutkan bahwa depresi adalah gangguan kesehatan mental umum yang ditandai dengan perasaan yang tertekan, perasaan bersalah, terjadi gangguan istirahat tidur, nafsu makan menurun, kehilangan kesenangan atau minat, merasa kurang berenergi serta konsentrasi menurun. Faktor lain yang dapat mengakibatkan terjadinya depresi pada lansia yaitu karena kematian pasangannya, menurunnya kemampuan fisik dan kesehatan, pensiun, interaksi sosial, kondisi keuangan, pekerjaan dan tempat tinggal [4].

Menurut hasil studi kasus Botvin et al., [5] menyebutkan bahwa ada banyak faktor benyebab anak menitipkan orang tuanya di panti antara lain karena adanya masalah keluarga dari segi ekonomi, timbulnya permasalahan dengan menantu, orang tua mengeluh kesepian karena anggota keluarga yang lain sibuk bekerja, tidak ada tempattinggal karena rumah dijual, anak merasa direpotkan karena tingkat laku orang tua yang sudah memasuki usia lanjut, dan seringkali anak tidak sabar dalam menghadapi orang tua lanjut usia. Hasil penelitian menurut Pae [6] menyebutkan bahwa tingkat depresi pada lansia yang tinggal di panti mayoritas mengalami depresi sedang dan lansia yang tinggal dirumah bersama keluarga mayoritas mengalami depresi tingkat ringan.

Stanley dan Beare (2005) menyebutkan bahwa lansia yang berada di institusi angka depresi ringan sampai sedang meningkat sebesar $50 \%$ sampai $70 \%$, hal tersebut didukung oleh penelitian di Malaysia, Korea, dan Iran bahwa prevalensi lansia di institusi pelayanan lebih tinggi dibandingkan dengan lansia yang tinggal di komunitas [7]. Depresi pada lansia lebih sulit dideteksi karena sering menutupi rasa kesepian atau kesedihan dengan lebih aktif mengikuti kegiatan [8]. Tentunya akan ada dampak yang terjadi akibat dari depresi pada lansia.

Dampak dari depresi pada lansia yang berkepanjangan dapat menurunkan status kesehatan dan lansia akan mengabaikan dirinya serta penampilannya [9]. Jacoby and Openheimer menyebutkan dampak dari depresi pada lansia yaitu munculnya tingkah laku melukai diri sampai melakukan percobaan bunuh diri [9].

Berdasarkan latar belakang diatas peneliti tertarik untuk melakukan penelitian menggunakan studi literature review tentang gambaran tingkat depresi pada lansia yang tinggal di panti sosial.

\section{Metode}

Metode yang digunakan dalam penelitian ini adalah studi deskriptif dengan pendekatan literature review. Dalam pencarian artikel menggunakan Google Scholar dan database PubMed dengan memasukka kata kunci Elderly OR geriatric OR lansia AND depression scale OR of depression OR tingkat depresi AND nursing home OR panti 


\section{Prosiding Seminar Nasional Kesehatan \\ Lembaga Penelitian dan Pengabdian Masyarakat Universitas Muhammadiyah Pekajangan Pekalongan}

sosial. Kriteria inklusi dalam pemilihan artikel meliputi populasi penelitian merupakan seorang lanjut usia yang tinggal di panti sosial, alat ukur yang digunakan yaitu instrumen Geriatric Depresssion Scale (GDS), dipublikasi dalam rentan waktu tahun 2011-2020, ditulis dengan bahasa Indonesia atau bahasa Inggris. Kriteria eksklusi dalam pemilihan artikel meliputi hasil penelitian tidak sesuai dengan tujuan penelitian ini, hasil dari telaah kritis pembahasan pada artikel tidak jelas, hasil dari telaah kritis isi artikel tidak lengkap.

- PubMed : Elderly OR geriatric AND depression scale OR level of depression AND nursing home

Jumlah artikel (dengan kata kunci tersebut) $=463$

- Google scholar : Elderly OR geriatric OR lansia AND depression scale OR of depression OR tingkat depresi AND nursing home OR panti sosial

Jumlah artikel (dengan kata kunci tersebut) $=644$

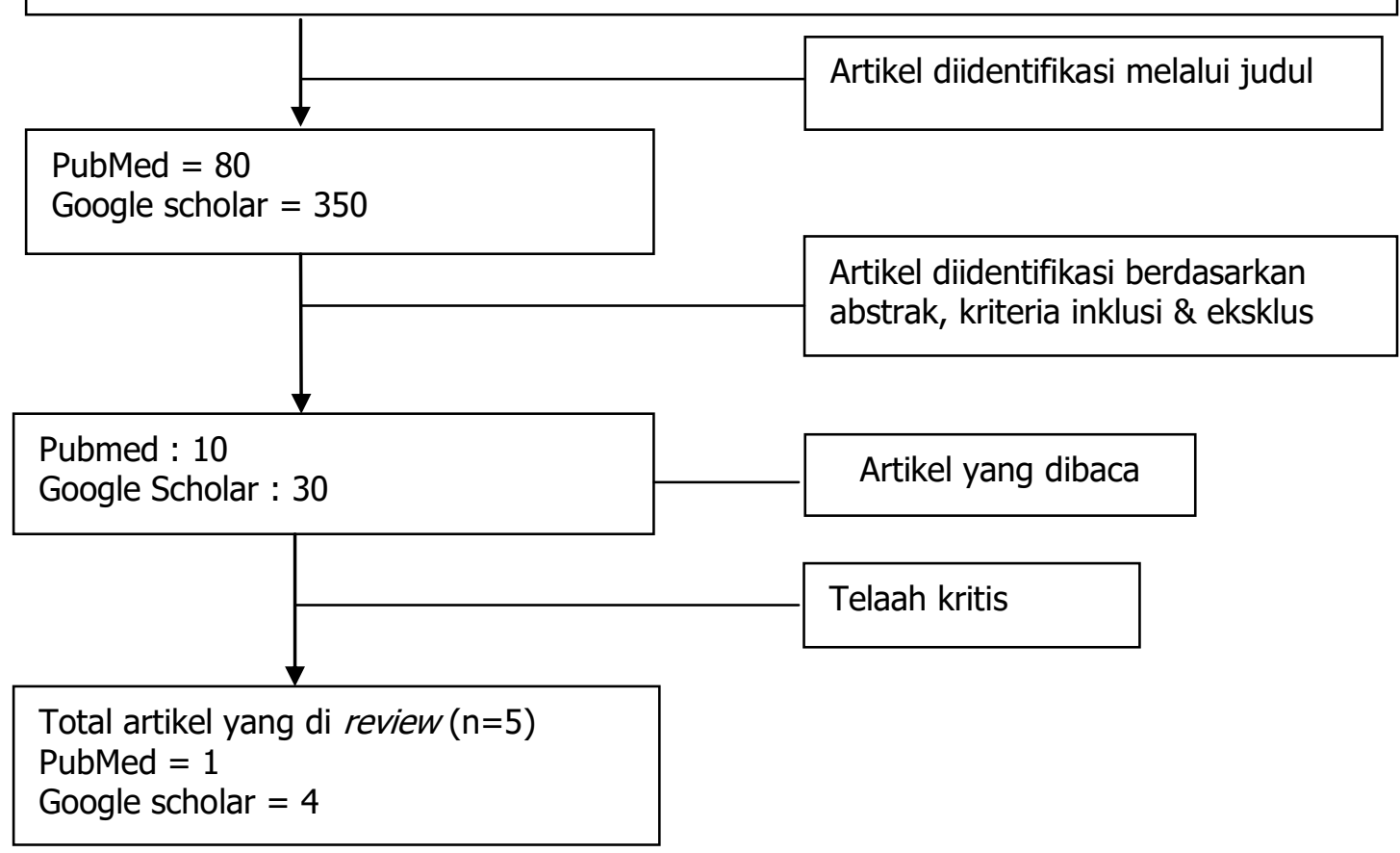

Dari kelima artikel tersebut telah dilakukaan telaah kritis menggunakan instrumen Joanna Briggs Institute Critical Appraisal dan layak untuk di review.

\section{Hasil dan Pembahasan}

\section{Hasil}

a. Karakteristik responden

1) Jenis kelamin

Berdasarkan hasil literature review pada ke-5 artikel karakteristik responden menurut jenis kelamin memperoleh distribusi frekuensi dan presentase. Responden berjenis kelamin perempuan lebih banyak dari pada laki-laki. 


\section{Prosiding Seminar Nasional Kesehatan \\ Lembaga Penelitian dan Pengabdian Masyarakat \\ Universitas Muhammadiyah Pekajangan Pekalongan}

Tabel 3.1 Karakteristik responden berdasarkan jenis kelamin

\begin{tabular}{|c|c|c|c|c|c|c|}
\hline \multicolumn{2}{|c|}{ Artikel } & \multicolumn{4}{|c|}{ Jenis kelamin } & \multirow{3}{*}{$\begin{array}{c}\text { Total } \\
\text { (n) }\end{array}$} \\
\hline \multirow[b]{2}{*}{ Penulis } & \multirow[b]{2}{*}{ Tahun } & \multicolumn{2}{|c|}{ Laki-laki } & \multicolumn{2}{|c|}{ Perempuan } & \\
\hline & & $\mathrm{F}$ & $\%$ & $\mathrm{~F}$ & $\%$ & \\
\hline Nazemi, et.al & 2013 & 114 & 46,7 & 130 & 53,3 & 244 \\
\hline Mulyadi, et.al & 2016 & 12 & 27,9 & 31 & 72,1 & 43 \\
\hline Putri, et.al & 2016 & 21 & 28,4 & 53 & 71,6 & 74 \\
\hline Wulandari, et.al & 2020 & 30 & 41,1 & 43 & 58,9 & 73 \\
\hline Pambudi, et.al & 2020 & 12 & 38,7 & 19 & 61,3 & 31 \\
\hline \multicolumn{2}{|c|}{ Total masing-masing jenis kelamin } & 189 & 40,6 & 276 & 59,4 & 465 \\
\hline
\end{tabular}

2) Usia

Berdasarkan hasil literatur review pada ke-5 artikel karakteristik responden berdasarkan usia dibedakan menjadi 3 rentang usia yaitu usia 6074 tahun, 75-90 tahun dan > 90 tahun. Karakteristik responden berdasarkan usia yang paling banyak yaitu rentang usia 60-74 tahun.

Tabel 3.2 karakteristik responden berdasarkan usia

\begin{tabular}{|c|c|c|c|c|c|c|c|c|}
\hline \multicolumn{2}{|l|}{ Artikel } & \multicolumn{6}{|c|}{ Usia } & \multirow{3}{*}{$\begin{array}{c}\text { Total } \\
\text { (n) }\end{array}$} \\
\hline \multirow[b]{2}{*}{ Penulis } & \multirow[b]{2}{*}{ Tahun } & \multicolumn{2}{|c|}{$60-74$ tahun } & \multicolumn{2}{|c|}{$75-90$ tahun } & \multicolumn{2}{|c|}{$>90$ tahun } & \\
\hline & & $\mathrm{F}$ & $\%$ & $\mathrm{~F}$ & $\%$ & $\mathrm{~F}$ & $\%$ & \\
\hline Nazemi, et.al & 2013 & 112 & 45,9 & 132 & 54,1 & 0 & 0,0 & 244 \\
\hline Mulyadi, et.al & 2016 & 22 & 51,2 & 21 & 8,8 & 0 & 0,0 & 43 \\
\hline Putri, et.al & 2016 & 56 & 75,7 & 17 & 23,0 & 1 & 1,3 & 74 \\
\hline Wulandari, et.al & 2020 & 45 & 61,6 & 28 & 38,4 & 0 & 0,0 & 73 \\
\hline Pambudi, et.al & 2020 & 15 & 48,4 & 16 & 51,6 & 0 & 0,0 & 31 \\
\hline $\begin{array}{l}\text { Total masing-masing } \\
\text { Usia }\end{array}$ & & 250 & 53,8 & 214 & 46,1 & 1 & 0,1 & 465 \\
\hline
\end{tabular}

3) Status pendidikan

Hasil review dari ke-5 artikel terdapat 2 artikel yang memunculkan karakteristik responden berdasarkan status pendidikan. Dimana artikel dari Nazemi, et.al [10] mengategorikan status pendidikan dengan buta huruf, sekolah dasar/sekolah menengah dan diploma/sarjana sedangkan artikel dari Wulandari, et.al [11] mengategorikan status pendidikan dengan tidak sekolah, SD, SMP, SMA. Responden paling banyak yaitu dengan status pendidikan tidak sekolah/buta huruf.

Tabel 3.3 Karakteristik responden berdasarkan status pendidikan

\begin{tabular}{|c|c|c|c|c|c|c|c|c|c|c|c|c|}
\hline \multirow{3}{*}{ Penulis } & \multicolumn{11}{|c|}{ Status pendidikan } & \multirow{3}{*}{$\begin{array}{c}\text { Tot } \\
\text { al } \\
\text { (n) }\end{array}$} \\
\hline & Tahun & $\begin{array}{r}\text { Tid } \\
\text { seko } \\
\text { ta I }\end{array}$ & $\begin{array}{l}\mathrm{k} \\
\text { ah/bu } \\
\text { uruf }\end{array}$ & \multicolumn{2}{|c|}{$\mathrm{SD}$} & \multicolumn{2}{|c|}{ SMP } & \multicolumn{2}{|c|}{ SMA } & \multicolumn{2}{|r|}{ PT } & \\
\hline & & $\mathrm{F}$ & $\%$ & $\mathrm{~F}$ & $\%$ & $\mathrm{~F}$ & $\%$ & $\mathrm{~F}$ & $\%$ & $\mathrm{~F}$ & $\%$ & \\
\hline Nazemi, et.al & 2013 & 106 & 43,5 & 0 & 0,0 & 0 & 0,0 & 73 & 9,9 & 65 & 26,7 & 244 \\
\hline Wulandari,et.al & 2020 & 38 & 52,1 & 14 & 9,2 & 11 & 5,1 & 10 & 3,7 & 0 & 0,0 & 73 \\
\hline $\begin{array}{l}\text { Total masing-masing } \\
\text { status pendidikan }\end{array}$ & & 144 & 45,4 & 14 & 4,4 & 11 & 3,5 & 83 & 26,2 & 65 & 20,5 & 317 \\
\hline
\end{tabular}




\section{Prosiding Seminar Nasional Kesehatan \\ Lembaga Penelitian dan Pengabdian Masyarakat \\ Universitas Muhammadiyah Pekajangan Pekalongan}

2021

4) Status pernikahan

Hasil literatur review terhadap ke-5 artikel terdapat 2 artikel yang memunculkan status pernikahan dimana artikel dari Nazemi [10] mengategorikan status pernikahan dengan menikah, tunggal dan bercerai sedangkan artikel dari Wulandari [11] mengategorikan status pernikahan dengan menikah, duda/janda dan tidak menikah. Responden paling banyak dengan status menikah yaitu 197 orang.

Tabel 3.4 Karakteristik responden berdasarkan status pernikahan

\begin{tabular}{|c|c|c|c|c|c|c|c|c|}
\hline \multirow{3}{*}{ Penulis } & \multicolumn{7}{|c|}{ Status pernikahan } & \multirow{3}{*}{$\begin{array}{c}\text { Total } \\
\text { (n) }\end{array}$} \\
\hline & \multirow[t]{2}{*}{ Tahun } & \multicolumn{2}{|c|}{ Menikah } & \multicolumn{2}{|c|}{$\begin{array}{l}\text { Janda/duda } \\
\text { atau Bercerai }\end{array}$} & \multicolumn{2}{|c|}{$\begin{array}{c}\text { Tunggal atau } \\
\text { Tidak } \\
\text { menikah }\end{array}$} & \\
\hline & & $F$ & $\%$ & $F$ & $\%$ & $F$ & $\%$ & \\
\hline Nazemi, et.al & 2013 & 166 & 68,0 & 36 & 14,8 & 42 & 17,2 & 244 \\
\hline Wulandari,et.al & 2020 & 31 & 42,5 & 34 & 46,6 & 8 & 10,9 & 73 \\
\hline $\begin{array}{l}\text { Total masing-masing } \\
\text { status pernikahan }\end{array}$ & & 197 & 62,1 & 70 & 22,1 & 50 & 15,8 & 317 \\
\hline
\end{tabular}

5) Riwayat penyakit

Hasil literatur review dari ke-5 artikel terdapat 2 artikel yang memunculkan data riwayat penyakit yaitu dari penelitian Putri, et.al [7] dan Wulandari, et.al [11]. Responden paling banyak dengan kategori ada riwayat penyakit.

Tabel 3.5 Karakteristik responden berdasarkan riwayat penyakit

\begin{tabular}{|c|c|c|c|c|c|c|}
\hline \multicolumn{2}{|c|}{ Artikel } & \multicolumn{4}{|c|}{ Riwayat penyakit } & \multirow{3}{*}{$\begin{array}{c}\text { Tota } \\
\text { (n) }\end{array}$} \\
\hline \multirow[b]{2}{*}{ Penulis } & \multirow[b]{2}{*}{ Tahun } & \multicolumn{2}{|c|}{ Ada } & \multicolumn{2}{|c|}{ Tidak ada } & \\
\hline & & $\mathrm{F}$ & $\%$ & $\mathrm{~F}$ & $\%$ & \\
\hline Putri, et.al & 2016 & 59 & 79,7 & 15 & 20,3 & 74 \\
\hline Wulandari,et.al & 2020 & 49 & 62,1 & 24 & 32,9 & 73 \\
\hline Total masing-mas & penyakit & 108 & 73,5 & 39 & 26,5 & 147 \\
\hline
\end{tabular}

6) Tingkat depresi

Dari ke-5 artikel gambaran tingkat depresi pada lansiayang tinggal di panti sosial responden terbanyak merupakan lansia yang mengalami tingkat depresi ringan.

Tabel 3.6 Tingkat depresi pada lansia yang tinggal di panti social

\begin{tabular}{|c|c|c|c|c|c|c|c|c|c|c|}
\hline \multirow{2}{*}{\multicolumn{2}{|c|}{ Artikel }} & \multicolumn{8}{|c|}{ Tingkat depresi } & \multirow{3}{*}{$\begin{array}{c}\text { Total } \\
\text { (n) }\end{array}$} \\
\hline & & \multicolumn{2}{|l|}{ Normal } & \multicolumn{2}{|l|}{ Ringan } & \multicolumn{2}{|l|}{ Sedang } & \multicolumn{2}{|l|}{ Berat } & \\
\hline Penulis & Tahun & $\mathrm{F}$ & $\%$ & $\mathrm{~F}$ & $\%$ & $\mathrm{~F}$ & $\%$ & $\mathrm{~F}$ & $\%$ & \\
\hline Nazemi, et.al & 2013 & 4 & 9,8 & 122 & 50,0 & 72 & 29,5 & 26 & 10,7 & 244 \\
\hline Mulyadi, et.al & 2016 & 9 & 21,0 & 31 & 72,0 & 3 & 7,0 & 0 & 0,0 & 43 \\
\hline Putri, et.al & 2016 & 1 & 41,9 & 32 & 43,2 & 11 & 14,9 & 0 & 0,0 & 74 \\
\hline Wulandari,et. al & 2020 & 8 & 65,8 & 22 & 30,1 & 0 & 0,0 & 3 & 4,1 & 73 \\
\hline Pambudi,et.al & 2020 & 0 & 0,0 & 27 & 87,1 & 4 & 12,9 & 0 & 0,0 & 31 \\
\hline Total masing-masing & & 12 & 24,2 & 234 & 50,3 & 90 & 19,3 & 29 & 6,2 & \\
\hline Tingkat depresi & & & & & & & & & & 465 \\
\hline
\end{tabular}




\section{Prosiding Seminar Nasional Kesehatan 2021 \\ Lembaga Penelitian dan Pengabdian Masyarakat Universitas Muhammadiyah Pekajangan Pekalongan}

\section{Pembahasan}

a. Karakteristik responden lansia yang tinggal di panti sosial

Berdasarkan analisa data yang dilakukan ke lima artikel menghasilkan data frekuensi dan presentase dari karakteristik responden. Karakteristik responden yang ditemukan antara lain jenis kelamin, usia, status pendidikan, status pernikahan, dan riwayat penyakit.

1) Jenis kelamin

Jumlah responden berjenis kelamin perempuan lebih banyak dari pada laki-laki. Hal ini sejalan dengan penelitian Mumulati et al., [12] dan Hadipranoto et al., [13] yang menyatakan bahwa presentase jumlah responden yang tinggal di panti sosial lebih banyak berjenis kelamin perempuan dibanding responden berjenis kelamin laki-laki. Hal tersebut kemungkinan berhubungan dengan Angka Harapan Hidup di Indonesia lebih tinggi perempuan dibandingkan laki-laki. Berdasarkan data dari Badan Pusat Statistik Indonesia, angka harapan hidup masyarakat Indonesia di tahun 2018 yaitu 73,19 tahun pada wanita dan 69,30 tahun pada pria [1]."

2) Usia

Hasil review dari ke lima artikel semua responden yang tinggal di panti sosial merupakan seseorang yang sudah berusia 60 tahun keatas. Beberapa faktor penyebab lansia tinggal di panti sosial yaitu ada faktor intern dan faktor ekstern. Faktor intern merupakan faktor yang berasal dari dalam diri individu, yang termasuk kedalam faktor intern lansia tinggal di Panti merupakan faktor perubahan struktur keluarga, faktor sosialisasi lansia dan juga faktor tidak ingin merepotkan anak.Faktor ekstern merupakan faktor dari luar diri individu,yang termasuk kedalam faktor ektern lansia tinggal di Panti merupakan faktor tidak ada yang memperhatikan, faktor bermasalah dengan keluarga serta aktor pelayanan dan fasilitas di Panti [14].

3) Status pendidikan

Lansia yang mempunyai tingkat pendidikan tinggi, akan mempunyai jangkauan yang lebih baik terhadap informasi mengenai kesehatan, lebih aktif menentukan sikap, dan lebih mandiri mengambil tindakan perawatan yang akan diambil, selain itu akan mudah menerima informasi baru mengenai kesehatannya dan mampu menyaring hal-hal positif dalam menghadapi kesehatan [15].

4) Status pernikahan

Hasil penelitian dari ke dua artikel yang memunculkan status pernikahan mendapatkan hasil paling banyak dengan status menikah. Hal ini sejalan dengan penelitian dari Dina Andesty dan Fariani Syahru tahun 2019 yang menyebutkan bahwa responden yang tinggal di panti sosial terbanyak dengan status menikah. Walaupun lansia memiliki status menikah tetapi pada kenyataannya banyak lansia yang berstatus menikah tetapi tidak tinggal bersama pasangannya di panti, beberapa ada yang pasangannya ikut bersama anak dan ada yang pisah kota [16]. Perubahan struktur keluarga seperti anak 


\section{Prosiding Seminar Nasional Kesehatan 2021 Lembaga Penelitian dan Pengabdian Masyarakat Universitas Muhammadiyah Pekajangan Pekalongan}

yang sudah menikah sehingga membentuk keluarga sendiri yang akan membuat orang tua tinggal hanya berdua. Hal tersebut akan semakin membuat lansia kesepian yang mengakibatkan merasa terlantar [14].

Menurut hasil studi kasus [5] yang berjudul Lansia Yang Menghuni Panti Werdha menyebutkan bahwa ada banyak faktor benyebab anak menitipkan orang tuanya di panti antara lain karena adanya masalah keluarga dari segi ekonomi, timbulnya permasalahan dengan menantu, orang tua mengeluh kesepian karena anggota keluarga yang lain sibuk bekerja, tidak ada tempat tinggal karena rumah dijual, anak merasa direpotkan karena tingkat laku orang tua yang sudah memasuki usia lanjut, dan seringkali anak tidak sabar dalam menghadapi orang tua lanjut usia.

5) Riwayat penyakit

Dari hasil review tersebut didapatkan hasil paling banyak kategori responden yang mempunyai riwayat penyakit. Kelompok lansia merupakan salah satu populasi yang beresiko memiliki banyak penyakit, hal ini terkait dengan teori penurunan cadangan fisiologis tubuh sehingga pada lanjut usia akan rentan terhadap serangan penyakit. Seiring pertambahan usia maka akan berkurang cadangan fisiologis tubuh, sehingga semakin rentan terkena penyakit [17].

b. Gambaran tingkat depresi pada lansia yang tinggal di panti social

Depresi dapat diukur menggunakan instrumen Geriatric Depression Scale dengan kategori normal (0-4), depresi ringan (5-8), depresi sedang (9-11), dan depresi berat (12-15). Dari ke lima artikel yang di review tingkat depresi pada lansia yang tinggal di panti sosial merupakan lansia yang mengalami tingkat depresi ringan.

Penelitian dari Pae [6] menyebutkan bahwa lansia yang berada di panti werdha lebih beresiko mengalami depresi karena lansia yang tinggal di panti jarangsekali dapat berkumpul dengan keluarga mereka atau bahkan lansia tidak memiliki keluarga lagi. Kegiatan yang dilakukan lansia di panti werdha juga tidak banyak dan lansia sangat jarang keluar panti karena keterbatasan kemampuan berjalan. Sedangkan lansia yang tinggal di rumah memiliki mekanisme koping yang baik saat menghadapi suatu masalah dapat bercerita kepadakeluarga. Dan lansia yang tinggal di rumah juga memiliki perkumpulan seperti pengajian, arisan, senam dan kegiatan lain di luar rumah.

Jumlah responden dalam penelitian ini lebih banyak berjenis kelamin perempuan. Hasil penelitian menurut Mumulati [12] menyebutkan bahwa lansia perempuan lebih banyak mengalami depresi dari pada lansia laki-laki. Hal tersebut terjadi karena lansia perempuan lebih sering terpapar faktor-faktor yang menyebabkan depresi [18]. Pada umumnya depresi pada lansia laki-laki sama dengan lansia perempuan, namun seringkali depresi pada laki-laki lebih sulit diketahui karena sejumlah lansia laki-laki yang tidak mencari atau menerima bantuan dan karena itu depresi pada mereka tetap tidak terdiagnosis dan tidak terobati [19]. Penelitian lain mengatakan bahwa koping lansia perempuan lebih baik dari pada lansia laki-laki dalam menghadapi masalah. Lansia perempuan 


\section{Prosiding Seminar Nasional Kesehatan 2021 \\ Lembaga Penelitian dan Pengabdian Masyarakat Universitas Muhammadiyah Pekajangan Pekalongan}

sering menggunakan koping emotion focused (misalnya dengan berkata pada diri sendiri karena mendapatkan masalah dan menangis) dan seeking support (misalnya mencari seseorang profesional untuk membantu menyelesaikan masalah, berdoa, berserah diri kepada Tuhan Yang Maha Esa) [20].

Responden dalam penelitian ini paling banyak yaitu dengan status pendidikan tidak sekolah/buta huruf. Hasil penelitian menurut Wulandari [11] menyebutkan bahwa status pendidikan kategori tidak sekolah paling banyak mengalami depresi. Status pendidikan sangat berpengaruh dalam kemampuan kognitif yaitu suatu bentuk mediator antara kejadian dalam hidup dengan mood, sehingga kurangnya pendidikan dapat menjadi faktor risiko lansia menderita depresi [8]. Semakin tinggi pendidikan maka akan membuat lansia memiliki pemikiran terbuka sehingga mudah dalam penerimaan hal-hal baru. Sebaliknya, semakin rendah pendidikan membuat lansia memiliki pemikiran tertutup sehingga membuat lansia tidak berkembang [12].

Depresi dapat diatasi dengan berbagai penanganan baik secara non farmakologi atau psikologis seperti terapi, konseling, dan dukungan sosial [21]. Intervensi keperawatan secara spiritual islam yang dapat dterapkan untuk menurunkan tingkat depresi yaitu mindfulness spiritual islam. Mindfulness spiritual islam merupakan suatu latihan yang melibatkan Allah SWT dalam setiap proses dengan tujuan membantu individu untuk secara sadar memahami kondisi atau pengalaman yang dihadapi bukan sebagai kebetulan tetapi peristiwa dibuat oleh Allah SWT [22].

\section{Kesimpulan}

Depresi dikategorikan menjadi 4 tingkatan yaitu normal, depresi ringan, depresi sedang, dan depresi berat. Dari ke lima artikel tingkat depresi pada lansia yang tinggal di panti sosial paling banyak merupakan lansia yang mengalami tingkat depresi ringan $50,3 \%$.

\section{Referensi}

[1] Badan Pusat Statistik. (2019). Katalog: 4104001. Statistik Penduduk Lanjut Usia Di Indonesia 2019, xxvi + 258 halaman.

[2] Saragih, P. W. (2018). Faktor- Faktor Yang Mempengaruhi Stress Terhadap Lanjut Usia Di Posyandu Lansia Puskesmas Bromo.Jurnal Ilmiah Kohesi Vol. 2 No. 2 Mei 2018. 2(2), 25-33

[3] World Health Organization. (2012). Depression: a global public health concern. https://www.who.int/mental_health/management/depression/who_paper_depres sion_wfmh_2012.pdf diunduh pada 23 Maret 2021

[4] Wulandari, D. (2020). Gambaran kejadian depresi lansia di panti wredha dharma bhakti surakarta 1. 10(1), 11-17.

[5] Azizah, L. M. (2011). Keperawatan Lanjut Usia.Yogyakarta:Graha Ilmu.

[6] Botvin, G. J., Griffin, K. W., Singh, A., dkk. (2017). Lansia Yang Menghuni Panti Werdha [Universitas Airlangga]. In Children and Youth Services Review (Vol. 7, Issue 2). 


\section{Prosiding Seminar Nasional Kesehatan \\ Lembaga Penelitian dan Pengabdian Masyarakat

https://www.researchgate.net/publication/309289477\%0Ahttps://www.ecpat.org /wp-content/uploads/2016/10/Voluntourism-and-child-trafficking-into orphanages.pdf\%0Ahttp://www.soscvzambia.org.zm\%0Aunesdoc.unesco.org/im ages/0021/002157/215738E.pdf\%0Ahttps://thec

[7] Pae, K. (2017). Perbedaan Tingkat Depresi Pada Lansia Yang Tinggal Di Panti Werdha Dan Yang Tinggal Di Rumah Bersama Keluarga. Jurnal Ners Lentera, 5(1), 21-32.

[8] Putri, S. I., \& Fitriyani, P. (2016). Gambaran Tingkat Depresi Lansia yang Melakukan Senam Di Panti Sosial Tresna Werdha di Jakarta. Jurnal Keperaatanw Indonesia, 19(2), 92-99. https://doi.org/10.7454/jki.v19i2.464

[9] Livana, Susanti, Y., Darwati, L. E., \& Anggraeni, R. (2018). Gambaran Tingkat Depresi Lansia. NURSCOPE: Jurnal Keperawatan Dan Pemikiran IImiah, 4(4), 8093.

[10] Widianingrum, S. (2016). Gambaran Umum Karakteristik Lansia dengan Depresi di Panti Wilayah Kota Semarang. Universitas Diponegoro Semarang.

[11] Nazemi, L., Skoog, I., Karlsson, I., Hosseini, S., Hosseini, M., Hosseinzadeh, M. J., \& Mo-, M. R. (2013). Depression, Prevalence and Some Risk Factors in Elderly Nursing Homes in Tehran, Iran. 42(6), 559-569

[12] Wulandari, D. (2020). Gambaran kejadian depresi lansia di panti wredha dharma bhakti surakarta 1. 10(1), 11-17.

[13] Mumulati, S. B., Niman, S., Indriarini, M. Y., Tinggi, S., Kesehatan, I., Borromeus, S., Parahyangan, K. B., Barat, K. B., \& Barat, J. (2020). Hubungan pendidikan, usia, jenis kelamin, status pernikahan dan lama tinggal di panti werdha dengan kejadian depresi pada lansia. 8(3), 329-336

[14] Hadipranoto, H., Satyadi, H., \& Rostiana, R. (2020). Gambaran Kualitas Hidup Lansia Yang Tinggal Di Panti Sosial Tresna Wreda X Jakarta. Jurnal Muara IImu Sosial, Humaniora, Dan Seni, 4(1), 119.

https://doi.org/10.24912/jmishumsen.v4i1.7535.2020

[15] Supriani, D. (2021). faktor penyebab lansia tinggal di panti sosial tresna werdha kota bengkulu.

[16] Ngadiran, A., Kep, M., \& Pd, M. (2019). Hubungan Karakteristik ( Umur , Pendidikan , dan Lama Tinggal Di Panti) dengan Tingkat Kecemasan Lansia di Panti Wreda Charitas Cimahi. 13, 104-108.

[17] Andesty, D., \& Syahrul, F. (2019). Hubungan Interaksi Sosial Dengan Kualitas Hidup Lansia Di Unit Pelayanan Terpadu (Uptd) Griya Werdha Kota Surabaya Tahun 2017. The Indonesian Journal of Public Health, 13(2), 171.

https://doi.org/10.20473/ijph.v13i2.2018.171-182

[18] Al Rasyid, I., Syafrita, Y., \& Sastri, S. (2017). Hubungan Faktor Risiko dengan Fungsi Kognitif pada Lanjut Usia Kecamatan Padang Panjang Timur Kota Padang $\begin{array}{llll}\text { Panjang. Jurnal Kesehatan } & \text { 6(1), }\end{array}$ https://doi.org/10.25077/jka.v6i1.643

[19] Mulyadi, R. R., Mardijana, A., \& Nurdian, Y. (2016). Overview of Depression in The Elderly of UPT Pelayanan Sosial Lanjut Usia District Jember. 2(2), 7-11.

[20] Octavianti, M. M. (2013). Gambaran Depresi Pada Lanjut Usia Di Panti Sosial Tresna Werdha Mulia Dharma Kabupaten Kubu Raya Tahun 2012. Jurnal 


\section{Prosiding Seminar Nasional Kesehatan 2021 Lembaga Penelitian dan Pengabdian Masyarakat Universitas Muhammadiyah Pekajangan Pekalongan}

Mahasiswa PSPD FK Universitas Tanjungpura, 1(1).

http://jurnal.untan.ac.id/index.php/jfk/article/view/1783

[21] Prabhaswari, L., \& Putu Ariastuti, N. L. (2016). Gambaran Kejadian Depresi Pada Lanjut Usia Di Wilayah Kerja Puskesmas Petang I Kabupaten Badung Bali 2015. Intisari Sains Medis, 71), 47. https://doi.org/10.15562/ism.v7i1.100

[22] Dirgayunita, A. (2016). Depresi: Ciri, Penyebab dan Penangannya. Journal AnNafs: Kajian Penelitian Psikologi, 1 (1), 1-14. https://doi.org/10.33367/psi.v1i1.235

[23] Asiah, A., Dwidiyanti, M., \& Wijayanti, D. Y. (2019). Penurunan Tingkat Depresi pada Pasien dengan Intervensi Minfulness Spiritual Islam. Jurnal Keperawatan Jiwa, 7(3), 267. https://doi.org/10.26714/jkj.7.3.2019.267-274. 